\title{
The Impact of Teachers' Age, Gender and Experience on the Use of Information and Communication Technology in EFL Teaching
}

\author{
Hassan Saleh Mahdi ${ }^{1} \&$ Abdullah Sa'ad Al-Dera ${ }^{1}$ \\ ${ }^{1}$ English Department, College of Arts and Science, Najran University, Najran, Saudi Arabia \\ Correspondence: Hassan Saleh Mahdi, College of Arts and Science, Najran University, Najran, Saudi Arabia.
}

Received: March 6, 2013 Accepted: April 22, 2013 Online Published: May 8, 2013

doi:10.5539/elt.v6n6p57 URL: http://dx.doi.org/10.5539/elt.v6n6p57

\begin{abstract}
The integration of information and communication technology (ICT) into language teaching and learning depends on many factors. Some of these factors are associated with teachers. Teachers play a crucial role in the integration of ICT. This study investigates the impact of teacher's age, experience, and gender on the integration of ICT into language teaching. This study utilized a mixed-method approach of investigation, which applies both qualitative and quantitative methods. The instruments used for data collection were a survey and an interview. The survey was administered to 46 in-service EFL teachers working at Najran University, Saudi Arabia. Ten out of these participants were interviewed. The results indicate that there is no significant difference in using ICT between the two groups of teachers according to their age and experience. However, the results indicate that there is a difference between male and female teachers in using ICT in language teaching. Female teachers reported less use of ICT in their instruction than male teachers. Some suggestions are offered to improve the situation of ICT integration into language learning in EFL contexts.
\end{abstract}

Keywords: technology integration, Information and Communication Technology (ICT), Computer-Assisted Language Learning (CALL), teachers' experience, gender

\section{Introduction}

Technology has a great impact on almost all aspects of education. It provides many opportunities for language learning. It accelerates, enriches and improves basic language skills. Students can learn faster and easier at anytime, and anywhere. It also facilitates an active role of learners. However, the integration of ICT into language teaching depends on many factors which affect the success or the failure of its use. The majority of the studies in this area focused on teacher training, teachers' attitudes towards the ICT, and teachers' beliefs about the ICT in language learning (Chen, 2008; Egbert, Paulus \& Nakamichi, 2002; Hubbard, 2008; Park \& Son, 2009; Russell \& Bradley, 1997). Teachers' age, teaching experience, and gender are some of the factors that affect ICT integration into language teaching and learning. These factors have been examined by some studies (Egbert, Paulus \& Nakamichi, 2002; Teo, 2008; Todman, 2000; Yaghi, 2001). These studies have found different results. For example, two contrasted results are reported in the previous studies about the impact of teachers' gender on ICT integration. The first one found that teachers' gender affects the integration of ICT in language teaching and learning, but the second one found that teacher gender had no effect.

Therefore, the present study aims at investigating the effect of teachers' age, teaching experience, and gender on the integration of ICT into language teaching in EFL situations. The context of the study is different. Therefore, the results are supposed to be unique. In this context, female campuses are separated from male campuses. Female teachers teach only female students.

\section{Literature Review}

Integration of ICT in teaching does not simply mean the installment of ICT labs equipped with many computers. Integration of ICT into a language curriculum should fulfill many conditions, including the introduction of the technology and then maintaining it to be user-friendly. Ruthven-Stuart (2003) points out that ICT integration has three stages; acquisition, introduction and maintenance. The acquisition stage means the purchase of hardware and the software. Introduction stage is composed of three elements: deciding where and how to locate the hardware and software; a comprehensive description of the role that the technology will play in language teaching; and the process of acquainting the stakeholders with the technology so that they can use it efficiently 
and effectively. Two aspects are considered in maintenance (i.e. maintained and operational). The installment of computer labs should not be considered an end in itself. Many factors should be considered to make ICT a successful and integrated part of language learning. For example, the participants of British Educational Communications and Technology Agency (Becta) felt that the most frequent individual factors which enable ICT use were: access to own personal laptop; availability of high quality resources; full access to software and hardware at all times; high level of technical support; access to an interactive whiteboard; and availability of good quality training. Therefore, a number of factors need to be considered to help ICT integration be successful. These factors can be examined in the light of three major categories as discussed below.

\subsection{Factors for Successful Integration of ICT}

\subsubsection{ICT Factors}

There are a number of issues regarding ICT to be considered when it is installed. For instance, ICT should involve appropriate hardware and software and be accessible at any time to both teachers and learners. In addition, ICT labs should be equipped with computers and other facilities that are suitable for teaching and learning purposes. There is no need to install highly technical labs with complex systems that only create difficulties for teachers and students. Another factor to be considered is the location of the computer lab. Jones (2001) points out that for the sake of effective learning, some locations are more appropriate than others. A CALL activity, for instance, that involves a small group or whole class and requires a teacher to be constantly at hand as a guide and adviser is more suitable to a laboratory than to a self-access centre. For effective integration, Chambers and Bax (2006) suggest that CALL facilities should not be separated from normal teaching space. The classroom should be organized in a way that allows for an easy move from CALL activity to non-CALL activity. McCarthy (1999) points out that the successful integration of any software presupposes an institutional infrastructure that provides sufficient appropriate hardware and IT link facilities in accessible locations and available at times when students and teachers need or want to use them. So it is necessary to consider the appropriateness of hardware and software, ease of the accessibility, and the location of the computers to make ICT integration successful. However, these factors can not alone facilitate the integration of ICT in language learning, some pedagogical factors are also necessary to be maintained.

\subsubsection{Pedagogical Factors}

Computers should serve language teaching and learning which means that teachers should know how to use computers to foster language teaching and learning. The success of ICT integration into the curriculum will vary from one place to another and from one class to another depending on the ways it is applied. It is important to train teachers with methods to use technology for language instruction. Cox, Preston, and Cox (1999) point out that if teachers are to be convinced of the value of using ICT in their teaching, their training should focus on pedagogical issues. Teachers should be equipped with skills for evaluating ICT materials, so they can adapt or develop suitable material for their own contexts. Also, it is very important for teachers to have a clear idea about when, what and where to use ICT materials. Chen (2008) states that teachers should be aware of proper technological tools for a particular task and the strategies for using the tools. Teachers should strike a balance between teacher time and computer time, teacher role and computer role. They ought to determine how they want software programs to support their teaching, particularly in cases where the language course necessitates the students spending a specific number of hours in the multimedia language laboratory.

The content, methodology and ICT suitability for the intended students are other issues to be considered. McCarthy (1994) points out that there should be a balance between the methodology, the linguistic content, and pedagogy. Moreover, quality issues such as accuracy, the availability of other supplementary materials in the form of printed workbooks and instructor manuals are also important. In addition to the pedagogical factors, individual factors related to the teachers and the learners are essential.

\subsubsection{Individual Factor}

Technology without teachers cannot create a good environment for language teaching and learning. Teacher and technology have important roles to play in education. Together, good teachers and good technology are essential to provide educational improvement. A number of studies have examined the impact of the teacher on ICT integration. (Becta, 2004; Chen, 2008; Egbert, Paulus \& Nakamichi, 2002; Hubbard, 2008; Mumtaz, 2000; Park \& Son, 2009; Russell \& Bradley, 1997). These studies concluded that teachers have a crucial impact on the integration of ICT into language teaching and learning. Many factors related to teachers affect the integration of ICT. The teachers' age (Teo, 2008; Yaghi, 2001), experience (Egbert, Paulus \& Nakamichi 2002; Russel and Bradley 1997), and gender (Russel \& Bradley, 1997; Todman 2000) are some of these factors. These studies have found that human factors are essential in ICT integration. For example, Becta (2004) finds that a significant 
determinant of teachers' level of engagement in ICT is their level of confidence in using technology. Chen (2008) suggests that continuous professional development would facilitate efficient and successful implementation of Internet use in language instruction. Mumtaz (2000) reviews a number of studies and concludes that successful integration of ICT needs to address three interlocking frameworks for change: the teacher, the school, and policy makers. Egbert, Paulus and Nakamichi (2002) find that teachers who use CALL activities are often those teachers who had experience with CALL. Park and Son (2009) point out that the teachers affirm that the quality of education depends exclusively on the quality of teachers, not the use of technologies. They also think that their positive attitude and continuous attempt to introduce new technologies and teaching materials to the class will improve language instruction. Findings from these studies suggest that the roles of teachers are critical in structuring the learning process, organizing activities, and evaluating materials equipped with CALL.

\subsection{Rationale and Research Questions}

The focus of previous studies was on teachers' ICT knowledge, teachers' beliefs, methods of using ICT in language teaching, and the nature of technology itself (the hardware and the software). Very few studies have examined the relationship between ICT integration within EFL teaching and learning contexts and factors related to the characteristics of teachers, such as teachers' age, experience, and gender. In addition, most of these studies were conducted in countries where technology was in its high position. The situation may be different if studies are conducted in developing countries or where technology use is still in its primitive stages. The teachers in these situations face different difficulties that may impede the use of ICT in teaching and learning a language. Their fresh use of ICT may affect the ways technology is integrated in language teaching. Therefore, the present study explores teacher-related factors that may affect the integration of ICT in teaching English as a foreign language. The study aims at addressing the following questions:

1. Do young teachers and old teachers differ in their uses of ICT in their instruction?

2. Do novice teachers and expert teachers differ in their uses of ICT in their instruction?

3. Do male teachers and female teachers differ in their uses of ICT in their instruction?

\section{Method}

\subsection{Research Design}

The methodology applied in this study is a mixed-method, including both quantitative and qualitative methods. The quantitative part of this study is a survey, whereas the qualitative part is an interview.

\subsection{Participants}

A total of 46 out of 70 EFL instructors at Najran University, Saudi Arabia, participated in this study, constituting a response rate of $65.7 \%$. The 46 teachers were selected out of a total of 70 teachers teaching English at Najran University in the academic year 2011-2012. Their demographic information was elicited through the first part of the survey administered to them. Their demographic background is shown in Table 1.

Table 1. Teachers' Background Information

\begin{tabular}{llll}
\hline Category & Groups & $\begin{array}{l}\text { Number of } \\
\text { participants }\end{array}$ & Percentage \\
\hline \multirow{2}{*}{ Age } & $20-40$ years & 27 & $58.69 \%$ \\
\cline { 2 - 4 } & $41-60$ & 19 & $41.31 \%$ \\
\hline \multirow{2}{*}{ Gender } & Male & 32 & $69.56 \%$ \\
\cline { 2 - 4 } & Female & 14 & $30.44 \%$ \\
\hline Teaching experience & $1-10$ years & 28 & $60.86 \%$ \\
\cline { 2 - 4 } & $11-25$ years & 18 & $39.14 \%$ \\
\hline
\end{tabular}

Table 1 shows that 27 teachers were under the age of forty years, and 19 teachers were above the age of 40 years. A total of 32 male teachers and 14 female teachers participated in the study. According to their teaching experience, 28 teachers have been teaching English for less than 10 years, whereas 18 teachers have teaching English for more than 10 years. The division of teachers into groups according to their ages and years of teaching was performed to check if the age and teaching experience have any kind of impact on ICT integration. The division was not based on specific criteria. However, it is meant to infer if there were any significant differences between the groups. 


\subsection{Data Collection Tools}

A survey (Appendix A) was developed to examine the factors that affect the respondents' use of ICT in their teaching. It included two sections which sought their demographic background, and their ICT knowledge and use in teaching. The items of the survey were based on (Chen, 2008) with some modifications to match the research questions. A structured interview was developed for the qualitative part of the study. Specific questions based on the research questions were prepared.

\subsection{Procedure}

The survey was administered to all the EFL instructors at English Department at Najran University, Saudi Arabia $(\mathrm{n}=70)$. A total of 50 survey papers were collected. Forty-six were included in the analysis. The other four were rejected because they were incomplete. A follow-up interview was held with ten EFL teachers from those who responded to the survey. The selection of these teachers was based on the following criteria: (a) those who showed their willingness to participate in the interview, as they replied to the last question of the survey; and (b) those whose answers to the survey required more clarifications.

\subsection{Data Analysis Procedures}

The survey responses were coded and statistically analyzed to determine the mean, frequency and percentage of each item. The responses were examined under three categories (i.e. age, teaching experience and gender). The totals in each category were computed and compared using SPSS package. T-test was applied to find out if there was any significant difference between the means of the groups. The result of each category is reported in the following section.

\section{Results and discussion}

\subsection{Teachers' Age and ICT Use}

Table 2. Teachers' age and ICT use

\begin{tabular}{|c|c|c|c|c|c|c|c|c|c|c|}
\hline \multirow[t]{3}{*}{ Question } & \multicolumn{4}{|c|}{ Group $1(20-40)$} & \multirow[t]{3}{*}{ Mean } & \multicolumn{2}{|c|}{ Group $2(41-60)$} & \multicolumn{2}{|c|}{$(n=19)$} & \multirow[t]{3}{*}{ Mean } \\
\hline & \multicolumn{2}{|c|}{ Yes } & \multicolumn{2}{|c|}{ No } & & \multicolumn{2}{|c|}{ Yes } & \multicolumn{2}{|c|}{ No } & \\
\hline & $\mathrm{N}$ & Percent & $\mathrm{N}$ & Percent & & $\mathrm{N}$ & Percent & $\mathrm{N}$ & Percent & \\
\hline $\begin{array}{l}\text { Do you have your own } \\
\text { personal computer? }\end{array}$ & 25 & $92.6 \%$ & 2 & $7.4 \%$ & 1.074 & 18 & $94 \%$ & 1 & $5.3 \%$ & 1.05 \\
\hline $\begin{array}{l}\text { Do you access the Internet in } \\
\text { your office? }\end{array}$ & 12 & $44.4 \%$ & 15 & $55.6 \%$ & 1.55 & 12 & $63.2 \%$ & 7 & $36.6 \%$ & 1.36 \\
\hline $\begin{array}{l}\text { Do you access the internet at } \\
\text { home? }\end{array}$ & 27 & $100 \%$ & 0 & $0 \%$ & 1.00 & 16 & $84.2 \%$ & 3 & $15.8 \%$ & 1.15 \\
\hline $\begin{array}{l}\text { Have you ever taught English } \\
\text { using a computer? }\end{array}$ & 19 & $70.4 \%$ & 8 & $29.6 \%$ & 1.29 & 17 & $89.5 \%$ & 2 & $10.5 \%$ & 1.10 \\
\hline $\begin{array}{l}\text { Have you ever taken a training } \\
\text { course in ICT? }\end{array}$ & 10 & $37 \%$ & 17 & $63 \%$ & 1.62 & 6 & $31.6 \%$ & 13 & $68.4 \%$ & 1.68 \\
\hline $\begin{array}{l}\text { Do you usually read about } \\
\text { ICT? }\end{array}$ & 15 & $55.6 \%$ & 12 & $44.4 \%$ & 1.44 & 8 & $42.1 \%$ & 11 & $57.9 \%$ & 1.57 \\
\hline
\end{tabular}

Table 2 shows that most of the teachers in both groups had their own personal computers, and they could access the internet at home. However, the teachers in the second group (41-60) reported that they could access the internet in their offices more than the teachers in the first group. Regarding using ICT in their teaching, more teachers in the second group (89.5\%) had used ICT in their teaching, whereas $70.4 \%$ of the teachers in the first group had used ICT in their teaching. However, the total number of the teachers who had used ICT in their instruction in both groups is similar (i.e. 19 and 17) which means that there is no significant difference between the two groups regarding the uses of ICT in English language teaching. Many of the respondents in both groups did not attend any training course in ICT.

Regarding reading about ICT and its uses in language teaching, 55.6\% of the respondents in the first group had read materials about ICT and its application in language teaching and learning, whereas $42.1 \%$ of the teachers in the second group had not read materials about ICT and its application in language teaching and learning. T-test results (Appendix B) indicate that there is no significant difference between the two groups regarding the 
integration of ICT in language learning. All the t-values shown in Appendix B are more than .05 which means that there is no significant difference between the young and old teachers.

Similarly, the results obtained from the interview indicate that most of the teachers felt that the age of the teacher had nothing to do with the integration of ICT in language teaching. Only one teacher stated that the age had an impact on the integration of ICT into language teaching. She stated that "young teachers are more enthusiastic and more energetic than senior ones". These findings contrast with those from some previous studies relating to the impact of teachers' age on ICT integration (e.g., Lee, 1997; Teo, 2008; Yaghi, 2001). These studies have found older teachers to be less confident with using computers. Lee (1997) as cited in Becta (2004) pointed out that many teachers of 'advanced age' will not have any computer education when in college, and as a result are in need of computer skills training to allow them to make use of computers in their work. Teo (2008) found that Singaporean pre-service teachers' attitudes for computer use were influenced by their age. Yaghi (2001) found that older teachers were less confident with using computers. In sum, the teacher's age had no effect on the implementation of ICT in language learning. Though, it may have indirect effect regarding the teaching experience. In other words, young teachers may have less teaching experience than senior teachers. The impact of teaching experience will be analyzed below.

\subsection{Teachers' Experience and ICT Use}

Table 3. Teachers' experience and ICT use

\begin{tabular}{|c|c|c|c|c|c|c|c|c|c|c|}
\hline \multirow[t]{3}{*}{ Question } & \multirow{2}{*}{\multicolumn{2}{|c|}{$\begin{array}{l}\text { Group 1 (1-10) } \\
\text { Yes }\end{array}$}} & \multicolumn{2}{|c|}{$(n=28)$} & \multirow[t]{3}{*}{ Mean } & \multicolumn{4}{|c|}{ Group $2(11-20) \quad(n=18)$} & \multirow[t]{3}{*}{ Mean } \\
\hline & & & No & & & \multicolumn{2}{|c|}{ Yes } & \multicolumn{2}{|c|}{ No } & \\
\hline & $\mathrm{N}$ & Percent & $\mathrm{N}$ & Percent & & $\mathrm{N}$ & Percent & $\mathrm{N}$ & Percent & \\
\hline $\begin{array}{l}\text { Do you have your own } \\
\text { personal computer? }\end{array}$ & 25 & $89.3 \%$ & 3 & $10.7 \%$ & 1.10 & 18 & $100 \%$ & 0 & $0 \%$ & 1.00 \\
\hline $\begin{array}{l}\text { Do you access the internet in } \\
\text { your office? }\end{array}$ & 12 & $42.9 \%$ & 16 & $57.1 \%$ & 1.57 & 12 & $66.7 \%$ & 6 & $33.3 \%$ & 1.33 \\
\hline $\begin{array}{l}\text { Do you access the internet at } \\
\text { home? }\end{array}$ & 7 & $25 \%$ & 21 & $75 \%$ & 1.00 & 1 & $5.6 \%$ & 17 & $94.4 \%$ & 1.16 \\
\hline $\begin{array}{l}\text { Have you ever taught English } \\
\text { using a computer? }\end{array}$ & 19 & $67.9 \%$ & 9 & $32.1 \%$ & 1.32 & 17 & $94.4 \%$ & 1 & $5.6 \%$ & 1.05 \\
\hline $\begin{array}{l}\text { Have you ever taken a training } \\
\text { course in ICT? }\end{array}$ & 7 & $25 \%$ & 21 & $75 \%$ & 1.75 & 9 & $50 \%$ & 9 & $50 \%$ & 1.50 \\
\hline $\begin{array}{l}\text { Do you usually read about } \\
\text { ICT? }\end{array}$ & 15 & $53.6 \%$ & 13 & $46.4 \%$ & 1.46 & 8 & $44.4 \%$ & 10 & $44.6 \%$ & 1.55 \\
\hline
\end{tabular}

Table 3 shows that the teachers in both groups had their own personal computers and accessed the internet much when they are in their offices. Also, a good number of them $(67.9 \%$ in the first group and $94.4 \%$ in the second group) had taught English using ICT. Regarding training courses, two-thirds (75\%) of the respondents in the first group did not attend any training course in ICT, while half of the respondents in the second group had attended training courses in ICT. T-test results (Appendix C) indicate that there is no significant difference between the two groups regarding the integration of ICT in language learning. Most of the t-values shown in Appendix C are more than .05 which means that there is no significant difference between the novice and experienced teachers. However, the teachers in the interview expressed two contrasting views about the impact of teachers' experience in integrating ICT into language teaching. Four of them felt that teaching experience had an influence in using ICT in teaching. One teacher stated that "proper integration of any teaching aids is enhanced by experience." On the other hand, six of them felt that teachers' experience did not matter. Instead, they distinguished two types of experience that affect ICT integration. The first is a general teaching experience with or without using ICT. The second is a specific teaching experience in which ICT was used during teaching. Regarding this distinction, the second one had an effect on integrating ICT, while the first one had nothing to do with the integration of ICT in language teaching. The results of this study indicate that there is no significant difference between experienced (i.e., teaching for more than ten years) and less experienced teachers (i.e., teaching for less than ten years).

The results of this study are in contradiction with the results of some of the previous studies which found that more experienced teachers had used ICT in their teaching. For example, Egbert, Paulus and Nakamichi (2002) found that teachers who used CALL activities were often those teachers who had experience with CALL. Russel 
and Bradley (1997) pointed out that the teachers' believed that more experience with computer was needed to feel competent in their use with class. Also, Teo (2008) found that the years of computer usage is positively correlated with level of computer confidence. Meskil, Mossop, DiAngelo and Pasquale (2002) compared the use of technology between novice and expert teachers. They found that those novice teachers were far less comfortable in their implementations than the more experienced teachers who had no formal training with computers but a great deal of classroom experience.

\subsection{Teachers' Gender and ICT Use}

Table 4. Teachers' gender and ICT use

\begin{tabular}{|c|c|c|c|c|c|c|c|c|c|c|}
\hline \multirow[t]{3}{*}{ Question } & \multicolumn{2}{|c|}{ Group 1 (male) } & \multirow{2}{*}{\multicolumn{2}{|c|}{$\frac{(\mathrm{n}=32)}{\text { No }}$}} & \multirow[t]{3}{*}{ Mean } & \multicolumn{3}{|c|}{ Group 2 (female) } & $(n=14)$ & \multirow[t]{3}{*}{ mean } \\
\hline & \multicolumn{2}{|c|}{ Yes } & & & & \multicolumn{2}{|c|}{ Yes } & \multicolumn{2}{|c|}{ No } & \\
\hline & $\mathrm{N}$ & Percent & $\mathrm{N}$ & Percent & & $\mathrm{N}$ & Percent & $\mathrm{N}$ & Percent & \\
\hline $\begin{array}{l}\text { Do you have your own personal } \\
\text { computer? }\end{array}$ & 31 & 96.9 & 1 & 3.1 & 1.03 & 12 & 85.7 & 2 & 14.3 & 1.14 \\
\hline $\begin{array}{l}\text { Do you access the internet in } \\
\text { your office? }\end{array}$ & 24 & 75 & 8 & 25 & 1.25 & 0 & 0 & 14 & 100 & 2.00 \\
\hline $\begin{array}{l}\text { Do you access the internet at } \\
\text { home? }\end{array}$ & 30 & 93.8 & 2 & 6.3 & 1.06 & 13 & 92.9 & 1 & 7.1 & 1.07 \\
\hline $\begin{array}{l}\text { Have you ever taught English } \\
\text { using a computer? }\end{array}$ & 29 & 90.6 & 3 & 9.4 & 1.09 & 7 & 50 & 7 & 50 & 1.50 \\
\hline $\begin{array}{l}\text { Have you ever taken a training } \\
\text { course in ICT? }\end{array}$ & 15 & 46.9 & 17 & 53.1 & 1.53 & 1 & 7.1 & 13 & 92.9 & 1.92 \\
\hline Do you usually read about ICT? & 20 & 62.5 & 12 & 37.5 & 1.37 & 3 & 21.4 & 11 & 78.6 & 1.78 \\
\hline
\end{tabular}

The results shown in Table 4 revealed some differences between male and female teachers in using ICT in language teaching. Two-thirds (75\%) of male teachers had accessed to the internet in their offices, whereas none of the female teachers had accessed the internet in their offices. Internet access at home is almost the same for both groups. The results show that $90.6 \%$ of male teachers had taught using computers in their teaching, whereas $50 \%$ of female teachers had taught using computers in their teaching. Also, $46.9 \%$ of the male teachers had attended ICT training courses, while only $7 \%$ of the female teachers had attended ICT training courses. However, the results obtained from the interview revealed that the gender of the teachers had no effect on integrating ICT in language teaching. T-test results (Appendix D) indicate that there is a significant difference between the two groups regarding the integration of ICT in language learning. Most of the t-values are less than .05 which means that there is no significant difference between the male and female teachers.

The results of this study are in contrast with some of the previous studies (e.g., Russel \& Bradley, 1997; Todman 2000). Russel and Bradley (1997) reported a correlation between gender and levels of computer anxiety, in which female teachers reported a greater degree of anxiety than male teachers. Todman (2000) concluded that research on computer self efficacy in general also revealed that males on average tend to acquire computer self efficacy faster than females. Significant differences between males and females were observed for technical ICT capabilities, and situational and longitudinal sustainability. In this case, male teachers' scores were higher.

The gender factor is an essential factor that affects the use of ICT in language teaching. It seems that the situation examined in this study did not help female teachers to get the maximum benefits of ICT in language teaching and learning. The situation examined by this study is unique. Female teachers and students have their own campuses. It is not allowed for female to attend male classes and vice versa. The system affects the ways that female teachers use ICT in their teaching. The continuous breakdowns hinder them use ICT smoothly. If any technical fault, they have to wait for male ICT expert to fix the problem in the evening when there is nobody inside the campus.

\section{Conclusions}

This study investigated the impact of teachers' age, experience and gender on ICT reported to use into language teaching and learning. The findings of this study concluded that there are no significant differences in ICT use regarding teachers' age and teaching experience. There is a significant difference between male and female teachers in the use of ICT in language teaching and learning. The results showed a lack of ICT training for most of the teachers who participated in the study. Therefore, ICT training courses should be provided to improve ICT 
integration into EFL language teaching and learning contexts.

These results present an initial step toward the successful integration of ICT into language teaching and learning at Saudi universities. The authors suggest that female teachers need to receive more support and be trained to use ICT in their instruction. In addition, seminars and workshops by female ICT experts should be provided for in-service female teachers. It is plausible that a number of limitations could have influenced the results obtained. The current sample of teachers is not representative of in-service teachers at Saudi universities. It would be better if a large number of in-service teachers from different parts of Saud Arabia participated in the study.

Several areas of future research can be conducted to better understand the impact of the teachers' age, gender and experience factors on ICT integration. This study needs to be replicated with a large number of teachers and within different contexts. In-depth longitudinal studies are needed to track the issues of successful ICT integration and examine any successful experiment.

\section{References}

Becta (British Educational Communications and Technology Agency). (2004). A Review of the Research Literature on Barriers to the uptake of ICT by teachers. Retrieved from http://dera.ioe.ac.uk/1603/1/becta_2004_barrierstouptake_litrev.pdf

Chambers, A., \& Bax, S. (2006). Making CALL work: Towards Normalisation. System, 34(4), 465-479. http://dx.doi.org/10.1016/j.system.2006.08.001

Chen, Y-L. (2008). A Mixed-method Study of EFL Teachers' Internet Use in Language Instruction. Teaching and Teacher Education, 24, 1015-1028. http://dx.doi.org/10.1016/j.tate.2007.07.002

Cox, M., Preston, C., \& Cox, K. (1999). What factors support or prevent teachers from using ICT in their classrooms? A paper presented at British Educational Research Association Annual Conference, University Of Sussex at Brighton. Retrieved from http://www.leeds.ac.uk/educol/documents/00001304.htm

Egbert, J., Paulus, T., \& Nakamichi, Y. (2002). The impact of CALL instruction on language classroom technology use: A foundation for rethinking CALL teacher education? Language Learning \& Technology, 6(3), 108-126. Retrieved from http://llt.msu.edu/vol6num3/egbert/default.html

Jones, F. (2001). CALL and the responsibilities of teachers and administrators. ELT Journal, 55(4), 360-367. http://dx.doi.org/10.1093/elt/55.4.360

Hubbard, P. (2008). CALL and the Future of Language Teacher Education. CALICO Journal, 25(2), 175-188. Retrieved from https://calico.org/memberBrowse.php?action=article\&id $=683$

McCarthy, B. (1999). Integration: The sine qua non of CALL. CALL-EJ Online, 1(2). Retrieved from http://callej.org/journal/1-2/mccarthy.html

Meskill, C., Mossop, J., DiAngelo, S., \& Pasquale, R. (2002). Expert and novice teachers talking technology: precepts, concepts, and misconcepts. Language Learning \& Technology, 6(3), 46-57. Retrieved from http://lt.msu.edu/vol6num3/pdf/meskill.pdf.

Mumtaz, S. (2000). Factors affecting teachers' use of information and communications technology: A review of the literature. Journal of Information Technology for Teacher Education, 9(3), 319-342. Retrieved from http://www.tandfonline.com/doi/abs/10.1080/14759390000200096\#preview

Park, C. N., \& Son, J. (2009). Implementing computer-assisted language learning in the EFL classroom: Teachers' perceptions and perspectives. International Journal of Pedagogies and Learning, 5(2), 80-101. http://dx.doi.org/10.5172/ijpl.5.2.80

Russell, G., \& Bradley, G. (1997). Teachers' computer anxiety: Implications for professional development. Education and Information Technologies, 2(1), 17-30. http://dx.doi.org/10.1023/A:1018680322904

Ruthven-Stuart, P. (2003). Integrating ICTs into a university language, curriculum: Can it be done successfully? Bulletin of Hokuriku University, 27, 159-176.

Teo, T. (2008). Pre-service teachers' attitudes towards computer use: A Singapore survey. Australian Journal of Educational Technology, 24(4), 413-424.

Todman, J. (2000). Gender differences in computer anxiety among university entrants since 1992. Computers \& Education, 34(1), 27-35. http://dx.doi.org/10.1016/S0360-1315(99)00036-6

Yaghi, H. M. (2001). Subject matter as a factor in educational computing by teachers in international settings. Journal of Educational Computing Research, 24(2), 139-154. 


\section{Appendix A}

\section{CALL Survey}

Dear colleagues,

This is a survey about the integration of CALL (Computer-Assisted Language Learning) into EFL curriculum in Saudi Universities. You are requested to answer the questions below. The answers will be used for research purposes. Your answers will be kept absolutely confidential. Thank you very much for your time and cooperation.

Sincerely,

\section{Section I: Personal Information}

1- Name (optional): Age: Gender: e-mail (optional):

2- Your highest educational degree: $\square$ Undergraduate Nationality:

3- Your current academic position: $\square$ Instructor $\quad \square$ Lecturer $\square$ Assistant Prof. $\square$ Associate Prof.

$\square$ Professor $\quad \square$ other (please specify)

4- What is your area of specialization? (E.g. Literature, Linguistics,)

5- How many years have you been teaching English?

6- You are currently teaching the following:

$\square$ English Major Courses (please mention the courses you teach)

$\square$ English Supplementary Courses (please mention the courses you teach)

7- What is the average number of students in your class?

\section{Section II: IT Knowledge and IT Use in Teaching}

8 - Do you have your own personal computer? $\square$ Yes $\square$ No
$\square$ Laptop $\quad \square$ Both
$\square$ No

If yes, what type of computer do you have? $\quad \square$ Desktop $\quad \square$ Laptop
9- Do you access the Internet in your office? $\quad \square$ Yes $\quad \square$ No

10 - Do you access the internet at home? $\square$ Yes $\square$ No

11- Do you have a high-speed Internet connection in your classroom? $\square$ Yes $\square$ No

12- Are there any computer facilities in your department for your students? $\square$ Yes $\quad \square$ No

13- How many computers are located in your classroom?

14- Have you ever taught English using a computer? $\square$ Yes $\quad \square$ No

15- Have you ever taken a training course in CALL? $\square$ Yes $\square$ No

16- Do you usually read about CALL, attend seminars, etc about CALL? $\square$ Yes $\quad \square$ No

17- Do you have a homepage on your university website? $\square$ Yes $\square$ No

Would you like to participate in the interview that will be conducted by the researchers very soon. $\square$ Yes $\square$ No 


\section{Appendix B. Output of the analysis of age variable}

\section{Independent Samples Test}

\begin{tabular}{|c|c|c|c|c|c|c|c|c|c|c|}
\hline & \multicolumn{2}{|c|}{$\begin{array}{l}\text { Levene's Test for } \\
\text { quality of Variances }\end{array}$} & \multicolumn{7}{|c|}{ t-test for Equality of Means } \\
\hline & & \multirow[b]{2}{*}{$\mathrm{F}$} & \multirow[b]{2}{*}{ Sig. } & \multirow[b]{2}{*}{$\mathrm{t}$} & \multirow[b]{2}{*}{ df } & \multirow[b]{2}{*}{ big. (2-tailed } & \multirow{2}{*}{$\begin{array}{c}\text { Mean } \\
\text { Difference }\end{array}$} & \multirow{2}{*}{$\begin{array}{l}\text { Std. Error } \\
\text { Difference }\end{array}$} & \multicolumn{2}{|c|}{$\begin{array}{c}95 \% \text { Confidence } \\
\text { Interval of the } \\
\text { Difference }\end{array}$} \\
\hline & & & & & & & & & Lower & Upper \\
\hline $\begin{array}{l}\text { Do you have your ov } \\
\text { personal computer? }\end{array}$ & $\begin{array}{l}\text { Equal varianc } \\
\text { assumed } \\
\text { Equal varianc } \\
\text { not assumed }\end{array}$ & .327 & .570 & $\begin{array}{l}.284 \\
.292\end{array}$ & $\begin{array}{r}44 \\
42.146\end{array}$ & $\begin{array}{l}.778 \\
.772\end{array}$ & $\begin{array}{l}.02144 \\
.02144\end{array}$ & $\begin{array}{l}.07553 \\
.07354\end{array}$ & $\begin{array}{l}-.13078 \\
-.12695\end{array}$ & $\begin{array}{l}.17366 \\
.16984\end{array}$ \\
\hline $\begin{array}{l}\text { Do you access the } \\
\text { Internet in your offict }\end{array}$ & $\begin{array}{l}\text { Equal varianc } \\
\text { assumed } \\
\text { Equal varianc } \\
\text { not assumed }\end{array}$ & 1.023 & .317 & $\begin{array}{l}1.245 \\
1.250\end{array}$ & $\begin{array}{r}44 \\
39.429\end{array}$ & .220 & $\begin{array}{l}.18713 \\
.18713\end{array}$ & $\begin{array}{l}.15032 \\
.14975\end{array}$ & $\begin{array}{l}-.11581 \\
-.11565\end{array}$ & $\begin{array}{l}.49008 \\
.48992\end{array}$ \\
\hline $\begin{array}{l}\text { Do you access the } \\
\text { internet at home? }\end{array}$ & $\begin{array}{l}\text { Equal varianc } \\
\text { assumed } \\
\text { Equal varianc } \\
\text { not assumed }\end{array}$ & 29.341 & .000 & $\begin{array}{l}-2.201 \\
-1.837\end{array}$ & $\begin{array}{r}44 \\
18.000\end{array}$ & .033 & $\begin{array}{l}-.15789 \\
-.15789\end{array}$ & $\begin{array}{l}.07175 \\
.08595\end{array}$ & $\begin{array}{l}-.30250 \\
-.33846\end{array}$ & $\begin{array}{r}-.01329 \\
.02267\end{array}$ \\
\hline $\begin{array}{l}\text { Do you have a } \\
\text { high-speed Internet } \\
\text { connection in your } \\
\text { classroom? }\end{array}$ & $\begin{array}{l}\text { Equal varianc } \\
\text { assumed } \\
\text { Equal varianc } \\
\text { not assumed }\end{array}$ & 4.752 & .035 & $\begin{array}{l}-1.020 \\
-1.073\end{array}$ & $\begin{array}{r}44 \\
43.822\end{array}$ & $\begin{array}{l}.313 \\
.289\end{array}$ & $\begin{array}{l}-.11696 \\
-.11696\end{array}$ & $\begin{array}{l}.11470 \\
.10900\end{array}$ & $\begin{array}{l}-.34813 \\
-.33665\end{array}$ & $\begin{array}{l}.11421 \\
.10273\end{array}$ \\
\hline $\begin{array}{l}\text { Are there any comp } \\
\text { facilities in your } \\
\text { department for your } \\
\text { students? }\end{array}$ & $\begin{array}{l}\text { Equal varianc } \\
\text { assumed } \\
\text { Equal varianc } \\
\text { not assumed }\end{array}$ & .283 & .597 & $\begin{array}{l}1.501 \\
1.504\end{array}$ & $\begin{array}{r}44 \\
39.159\end{array}$ & .140 & $\begin{array}{l}.22417 \\
.22417\end{array}$ & $\begin{array}{l}.14931 \\
.14904\end{array}$ & $\begin{array}{l}-.07675 \\
-.07725\end{array}$ & $\begin{array}{l}.52509 \\
.52559\end{array}$ \\
\hline $\begin{array}{l}\text { Have you ever taugh } \\
\text { English using a } \\
\text { computer? }\end{array}$ & $\begin{array}{l}\text { Equal varianc } \\
\text { assumed } \\
\text { Equal varianc } \\
\text { not assumed }\end{array}$ & 12.515 & .001 & $\begin{array}{l}1.554 \\
1.659\end{array}$ & $\begin{array}{r}44 \\
43.963\end{array}$ & .127 & $\begin{array}{l}.19103 \\
.19103\end{array}$ & $\begin{array}{l}.12296 \\
.11512\end{array}$ & $\begin{array}{l}-.05678 \\
-.04097\end{array}$ & $\begin{array}{l}.43885 \\
.42304\end{array}$ \\
\hline $\begin{array}{l}\text { Have you ever taker } \\
\text { training course in } \mathrm{Ct}\end{array}$ & $\begin{array}{l}\text { Equal varianc } \\
\text { assumed } \\
\text { Equal varianc } \\
\text { not assumed }\end{array}$ & .587 & .448 & $\begin{array}{l}-.375 \\
-.377\end{array}$ & $\begin{array}{r}44 \\
39.631\end{array}$ & .710 & $\begin{array}{l}-.05458 \\
-.05458\end{array}$ & $\begin{array}{l}.14559 \\
.14482\end{array}$ & $\begin{array}{l}-.34801 \\
-.34736\end{array}$ & $\begin{array}{l}.23884 \\
.23820\end{array}$ \\
\hline $\begin{array}{l}\text { Do you usually read } \\
\text { about CALL? }\end{array}$ & $\begin{array}{l}\text { Equal varianc } \\
\text { assumed } \\
\text { Equal varianc } \\
\text { not assumed }\end{array}$ & .098 & .755 & $\begin{array}{l}-.886 \\
-.886\end{array}$ & $\begin{array}{r}44 \\
38.865\end{array}$ & .380 & $\begin{array}{l}-.13450 \\
-.13450\end{array}$ & $\begin{array}{l}.15174 \\
.15179\end{array}$ & $\begin{array}{l}-.44031 \\
-.44156\end{array}$ & $\begin{array}{l}.17131 \\
.17255\end{array}$ \\
\hline $\begin{array}{l}\text { Do you have a } \\
\text { homepage on your } \\
\text { university website? }\end{array}$ & $\begin{array}{l}\text { Equal varianc } \\
\text { assumed } \\
\text { Equal varianc } \\
\text { not assumed }\end{array}$ & 1.168 & .286 & $\begin{array}{l}.689 \\
.684\end{array}$ & $\begin{array}{r}44 \\
37.867\end{array}$ & $\begin{array}{l}.494 \\
.498\end{array}$ & $\begin{array}{l}.10331 \\
.10331\end{array}$ & $\begin{array}{l}.14995 \\
.15106\end{array}$ & $\begin{array}{l}-.19889 \\
-.20253\end{array}$ & $\begin{array}{l}.40552 \\
.40916\end{array}$ \\
\hline $\begin{array}{l}\text { Does the course cor } \\
\text { any CALL materials: }\end{array}$ & $\begin{array}{l}\text { Equal varianc } \\
\text { assumed } \\
\text { Equal varianc } \\
\text { not assumed }\end{array}$ & 2.325 & .134 & $\begin{array}{l}.863 \\
.850\end{array}$ & $\begin{array}{r}44 \\
36.716\end{array}$ & $\begin{array}{l}.393 \\
.401\end{array}$ & $\begin{array}{l}.12476 \\
.12476\end{array}$ & $\begin{array}{l}.14461 \\
.14684\end{array}$ & $\begin{array}{l}-.16668 \\
-.17285\end{array}$ & $\begin{array}{l}.41620 \\
.42236\end{array}$ \\
\hline $\begin{array}{l}\text { Does the course ask } \\
\text { students to do online } \\
\text { exercises? }\end{array}$ & $\begin{array}{l}\text { Equal varianc } \\
\text { assumed } \\
\text { Equal varianc } \\
\text { not assumed }\end{array}$ & .172 & .680 & .207 & 37.486 & .837 & $\begin{array}{l}.02534 \\
.02534\end{array}$ & $\begin{array}{l}.12140 \\
.12263\end{array}$ & $\begin{array}{l}-.21933 \\
-.22301\end{array}$ & $\begin{array}{l}.27001 \\
.27370\end{array}$ \\
\hline $\begin{array}{l}\text { Does the course } \\
\text { encourage students } \\
\text { access the materials } \\
\text { online? }\end{array}$ & $\begin{array}{l}\text { Equal varianc } \\
\text { assumed } \\
\text { Equal varianc } \\
\text { not assumed }\end{array}$ & 1.165 & .286 & $\begin{array}{l}1.669 \\
1.653\end{array}$ & $\begin{array}{r}44 \\
37.538\end{array}$ & .107 & $\begin{array}{l}.24561 \\
.24561\end{array}$ & $\begin{array}{l}.14719 \\
.14863\end{array}$ & $\begin{array}{l}-.05104 \\
-.05538\end{array}$ & $\begin{array}{l}.54227 \\
.54661\end{array}$ \\
\hline
\end{tabular}




\section{Appendix C. Output of the analysis of experience variable}

Independent Samples Test

\begin{tabular}{|c|c|c|c|c|c|c|c|c|c|c|}
\hline & \multicolumn{2}{|c|}{$\begin{array}{l}\text { Levene's Test for } \\
\text { quality of Variance }\end{array}$} & \multicolumn{7}{|c|}{ t-test for Equality of Means } \\
\hline & & \multirow[b]{2}{*}{$\mathrm{F}$} & \multirow[b]{2}{*}{ Sig. } & \multirow[b]{2}{*}{$\mathrm{t}$} & \multirow[b]{2}{*}{ df } & \multirow{2}{*}{ ig. (2-tailed } & \multirow{2}{*}{$\begin{array}{c}\text { Mean } \\
\text { Difference }\end{array}$} & \multirow{2}{*}{$\begin{array}{l}\text { Std. Error } \\
\text { Difference }\end{array}$} & \multicolumn{2}{|c|}{$\begin{array}{l}95 \% \text { Confidence } \\
\text { Interval of the } \\
\text { Difference }\end{array}$} \\
\hline & & & & & & & & & Lower & Upper \\
\hline $\begin{array}{l}\text { Do you have your c } \\
\text { personal computer }\end{array}$ & $\begin{array}{l}\text { Equal varian } \\
\text { assumed } \\
\text { Equal variand } \\
\text { not assumed }\end{array}$ & 10.672 & .002 & $\begin{array}{l}1.437 \\
1.800\end{array}$ & $\begin{array}{r}44 \\
27.000\end{array}$ & $\begin{array}{l}.158 \\
.083\end{array}$ & $\begin{array}{l}.10714 \\
.10714\end{array}$ & $\begin{array}{l}.07454 \\
.05952\end{array}$ & $\begin{array}{l}-.04308 \\
-.01499\end{array}$ & $\begin{array}{l}.25737 \\
.22928\end{array}$ \\
\hline $\begin{array}{l}\text { Do you access the } \\
\text { Internet in your offil }\end{array}$ & $\begin{array}{l}\text { Equal varian } \\
\text { assumed } \\
\text { Equal variand } \\
\text { not assumed }\end{array}$ & 1.697 & .199 & $\begin{array}{l}1.587 \\
1.600\end{array}$ & $\begin{array}{r}44 \\
37.430\end{array}$ & $\begin{array}{l}.120 \\
.118\end{array}$ & $\begin{array}{l}.23810 \\
.23810\end{array}$ & $\begin{array}{l}.15007 \\
.14880\end{array}$ & $\begin{array}{l}-.06435 \\
-.06329\end{array}$ & $\begin{array}{l}.54054 \\
.53948\end{array}$ \\
\hline $\begin{array}{l}\text { Do you access the } \\
\text { internet at home? }\end{array}$ & $\begin{array}{l}\text { Equal varian } \\
\text { assumed } \\
\text { Equal variand } \\
\text { not assumed }\end{array}$ & 33.478 & .000 & $\begin{array}{l}-2.314 \\
-1.844\end{array}$ & $\begin{array}{r}44 \\
17.000\end{array}$ & $\begin{array}{l}.025 \\
.083\end{array}$ & $\begin{array}{l}-.16667 \\
-.16667\end{array}$ & $\begin{array}{l}.07201 \\
.09039\end{array}$ & $\begin{array}{l}-.31180 \\
-.35737\end{array}$ & $\begin{array}{l}-.02154 \\
.02403\end{array}$ \\
\hline $\begin{array}{l}\text { Do you have a } \\
\text { high-speed Interne } \\
\text { connection in your } \\
\text { classroom? }\end{array}$ & $\begin{array}{l}\text { Equal variand } \\
\text { assumed } \\
\text { Equal variand } \\
\text { not assumed }\end{array}$ & 17.079 & .000 & $\begin{array}{l}-1.715 \\
-1.941\end{array}$ & $\begin{array}{r}44 \\
42.881\end{array}$ & $\begin{array}{l}.093 \\
.059\end{array}$ & $\begin{array}{l}-.19444 \\
-.19444\end{array}$ & $\begin{array}{l}.11335 \\
.10015\end{array}$ & $\begin{array}{l}-.42290 \\
-.39644\end{array}$ & $\begin{array}{l}.03401 \\
.00755\end{array}$ \\
\hline $\begin{array}{l}\text { Are there any comr } \\
\text { facilities in your } \\
\text { department for you } \\
\text { students? }\end{array}$ & $\begin{array}{l}\text { Equal varian } \\
\text { assumed } \\
\text { Equal varian } \\
\text { not assumed }\end{array}$ & .288 & .594 & $\begin{array}{l}1.201 \\
1.202\end{array}$ & 36.533 & $\begin{array}{l}.236 \\
.237\end{array}$ & $\begin{array}{l}.18254 \\
.18254\end{array}$ & $\begin{array}{l}.15198 \\
.15182\end{array}$ & $\begin{array}{l}-.12375 \\
-.12521\end{array}$ & $\begin{array}{l}.48883 \\
.49029\end{array}$ \\
\hline $\begin{array}{l}\text { Have you ever taus } \\
\text { English using a } \\
\text { computer? }\end{array}$ & $\begin{array}{l}\text { Equal variand } \\
\text { assumed } \\
\text { Equal variand } \\
\text { not assumed }\end{array}$ & 34.690 & .000 & $\begin{array}{l}2.198 \\
2.516\end{array}$ & $\begin{array}{r}44 \\
41.866\end{array}$ & .033 & $\begin{array}{l}.26587 \\
.26587\end{array}$ & $\begin{array}{l}.12094 \\
.10566\end{array}$ & $\begin{array}{l}.02213 \\
.05262\end{array}$ & $\begin{array}{l}.50962 \\
.47913\end{array}$ \\
\hline $\begin{array}{l}\text { Have you ever tak } \epsilon \\
\text { training course in C }\end{array}$ & $\begin{array}{l}\text { Equal varian } \\
\text { assumed } \\
\text { Equal varian } \\
\text { not assumed }\end{array}$ & 5.739 & .021 & $\begin{array}{l}1.758 \\
1.699\end{array}$ & 44 & $\begin{array}{l}.086 \\
.099\end{array}$ & $\begin{array}{l}.25000 \\
.25000\end{array}$ & $\begin{array}{l}.14221 \\
.14714\end{array}$ & $\begin{array}{l}-.03661 \\
-.04960\end{array}$ & $\begin{array}{l}.53661 \\
.54960\end{array}$ \\
\hline $\begin{array}{l}\text { Do you usually reaı } \\
\text { about CALL? }\end{array}$ & $\begin{array}{l}\text { Equal varian } \\
\text { assumed } \\
\text { Equal variand } \\
\text { not assumed }\end{array}$ & .070 & .793 & $\begin{array}{l}-.593 \\
-.592\end{array}$ & $\begin{array}{r}44 \\
36.227\end{array}$ & $\begin{array}{l}.556 \\
.557\end{array}$ & $\begin{array}{l}-.09127 \\
-.09127\end{array}$ & $\begin{array}{l}.15384 \\
.15407\end{array}$ & $\begin{array}{l}-.40130 \\
-.40366\end{array}$ & $\begin{array}{l}.21876 \\
.22112\end{array}$ \\
\hline $\begin{array}{l}\text { Do you have a } \\
\text { homepage on your } \\
\text { university website? }\end{array}$ & $\begin{array}{l}\text { Equal varian } \\
\text { assumed } \\
\text { Equal variand } \\
\text { not assumed }\end{array}$ & 1.918 & .173 & $\begin{array}{l}1.583 \\
1.557\end{array}$ & 34.458 & $\begin{array}{l}.121 \\
.129\end{array}$ & $\begin{array}{l}.23413 \\
.23413\end{array}$ & $\begin{array}{l}.14794 \\
.15034\end{array}$ & $\begin{array}{l}-.06403 \\
-.07125\end{array}$ & $\begin{array}{l}.53229 \\
.53951\end{array}$ \\
\hline $\begin{array}{l}\text { Does the course cc } \\
\text { any CALL materials }\end{array}$ & $\begin{array}{l}\text { Equal variand } \\
\text { assumed } \\
\text { Equal variand } \\
\text { not assumed }\end{array}$ & .744 & .393 & $\begin{array}{l}.460 \\
.454\end{array}$ & 34.971 & .648 & $\begin{array}{l}.06746 \\
.06746\end{array}$ & $\begin{array}{l}.14677 \\
.14852\end{array}$ & $\begin{array}{l}-.22834 \\
-.23406\end{array}$ & $\begin{array}{l}.36326 \\
.36898\end{array}$ \\
\hline $\begin{array}{l}\text { Does the course as } \\
\text { students to do onlir } \\
\text { exercises? }\end{array}$ & $\begin{array}{l}\text { Equal varian } \\
\text { assumed } \\
\text { Equal variand } \\
\text { not assumed }\end{array}$ & .496 & .485 & $\begin{array}{l}.357 \\
.349\end{array}$ & 33.923 & .723 & $\begin{array}{l}.04365 \\
.04365\end{array}$ & $\begin{array}{l}.12236 \\
.12490\end{array}$ & $\begin{array}{l}-.20296 \\
-.21020\end{array}$ & $\begin{array}{l}.29026 \\
.29750\end{array}$ \\
\hline $\begin{array}{l}\text { Does the course } \\
\text { encourage student } \\
\text { access the materia } \\
\text { online? }\end{array}$ & $\begin{array}{l}\text { Equal varian } \\
\text { assumed } \\
\text { Equal varian } \\
\text { not assumed }\end{array}$ & .425 & .518 & $\begin{array}{l}2.684 \\
2.652\end{array}$ & 34.980 & .010 & $\begin{array}{l}.38095 \\
.38095\end{array}$ & $\begin{array}{l}.14195 \\
.14363\end{array}$ & $\begin{array}{l}.09487 \\
.08936\end{array}$ & $\begin{array}{l}.66704 \\
.67255\end{array}$ \\
\hline
\end{tabular}




\section{Appendix D. Output of the analysis of gender variable}

Independent Samples Test

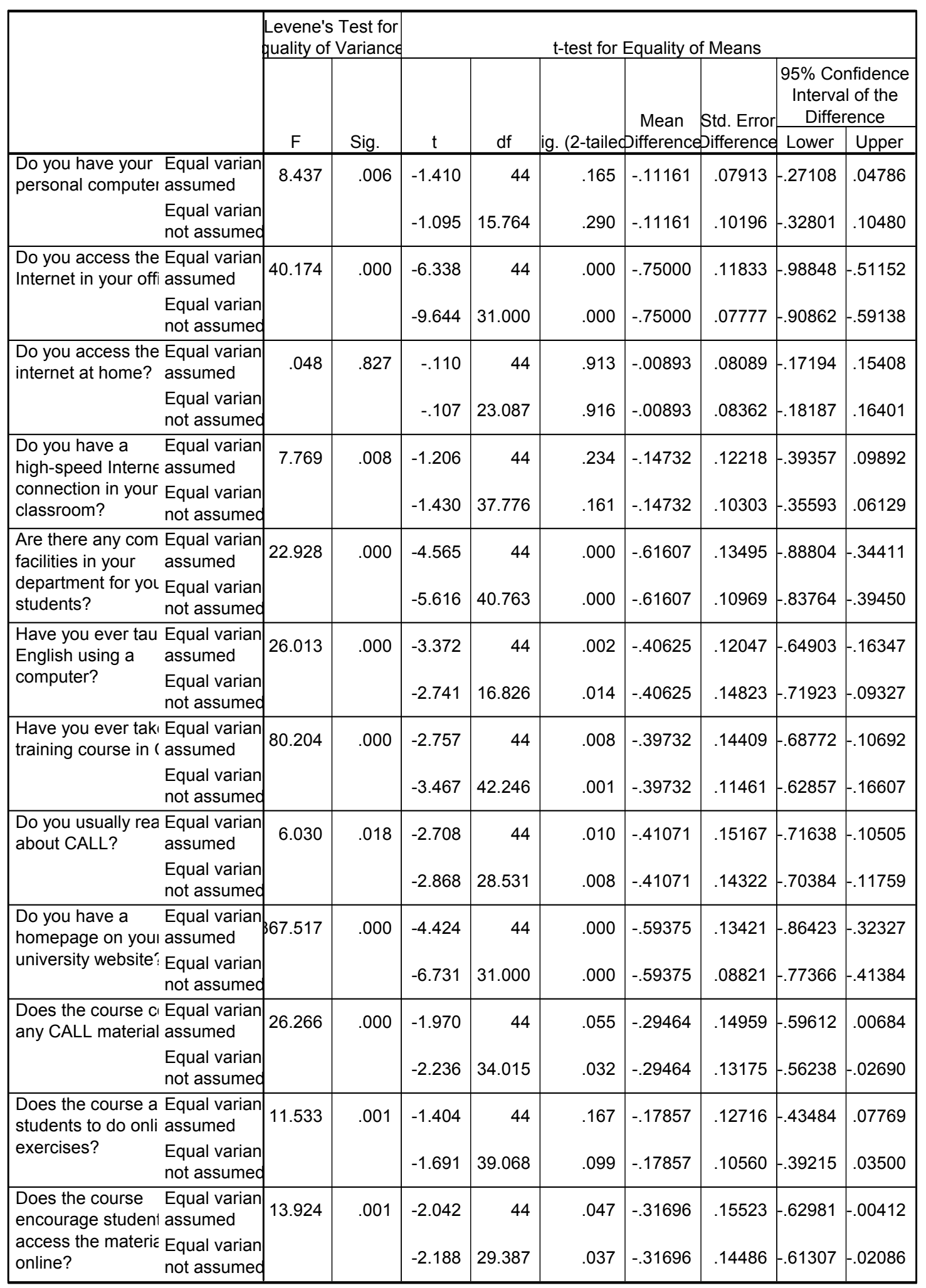

